\title{
HUBUNGAN ANTARA TINGKAT KEPATUHAN PERAWAT TERHADAP SOP (STANDAR OPERASIONAL PROSEDUR) PERAWATAN LUKA DENGAN PROSES PENYEMBUHAN LUKA PASIEN PASCABEDAH DI RSUD dr. H. ANDI ABDURRAHMAN NOOR
}

\author{
Farhandika Putra ${ }^{1}$, Muhammad Suhada ${ }^{2}$ \\ Program Studi S1 Keperawatan \\ Sekolah Tinggi Ilmu Kesehatan Darul Azhar Batulicin, Tanah Bumbu, 72171, Indonesia \\ e-mail:farhan85ners@yahoo.com
}

\begin{abstract}
ABSTRAK
Latar Belakang: SOP merupakan tata cara atau tahapan yang dibakukan dan harus dilalui untuk menyelesaikan suatu proses kerja tertentu dan merupakan bagian dari keterampilan perawat dalam mengaplikasikan ilmu yang dimilikinya. Luka adalah terputusnya kontinuitas suatu jaringan yang disebabkan adanya cidera atau psoses pembedahan. Proses penyembuhan luka dipengaruhi oleh beberapa faktor salah satunya adalah manajemen luka seperti perawatan luka. Tujuan dari penelitian ini adalah untuk mengetahui hubungan antara tingkat kepatuhan perawat terhadap SOP (Standar Operasional Prosedur) perawatan luka dengan proses penyembuhan luka pascabedah. Metode: Jenis penelitian ini adalah korelasi menggunakan desain cross sectional. Sampel pada penelitian ini adalah perawat berjumlah 20 orang dan pasien berjumlah 20 orang dengan menggunakan tekhnik purposive sampling. Penelitian ini dilakukan di ruang Bedah RSUD dr. H. Andi Abdurrahman Noor Kab. Tanah Bumbu. Hasil: Penelitian menunjukkan tingkat kepatuhan perawat dalam kategori sangat patuh yaitu (40\%) dan hasil observasi pada proses penyembuhan luka yaitu (55\%) berada pada tingkat kategori yang kurang baik. Setelah dilakukan uji statistik menggunakan uji Spearman Rank didapatkan nilai $P$ value $0,032<(0,05)$. Kesimpulan dari penelitian ini adalah terdapat hubungan antara tingkat kepatuhan perawat terhadap SOP (Standar Operasional Prosedur) perawatan luka dengan proses penyembuhan luka pasca bedah.

Kata kunci: Kepatuhan, Perawat, Proses Penyembuhan Luka, SOP Perawatan Luka Pascabedah.
\end{abstract}

Background:SOP is a procedure or stage that is standardized and must be passed to complete a particular work process and is part of the nurses' skills in applying their knowledge. Injuries are a break in the continuity of a tissue caused by an injury or surgical process. The wound healing process is influenced by several factors, one of which is wound management such as wound care. Objective: this study was to determine the correlation between the level of nurse obedience to SOP (Standard Operational Procedure) wound care with the wound healing process after surgery. Methods: This study was a correlation with using cross sectional design. The samples in this study were 20 nurses and 20 patients by using purposive sampling technique. This study was conducted in the RSUD dr. H. Andi Abdurrahman Noor Kabupaten Tanah Bumbu. Results: The study indicated that the level of nurse obedience in the very obedient category was (40\%) and the results of observations in the wound healing process were $(55 \%)$ at the level of the category that was not good. After statistical tests by using the Spearman Rank test obtained P value of 0.032 $<(0.05)$. Conclusion of this study, that there was correlation between the level of nurse obedience to SOP (Standard Operational Procedure) wound care with wound healing process after surgery.

Keywords: Obedience, Nurse, Wound Healing Process, SOP (Standard Operational Procedure) wound care, After Surger 


\section{Latar Belakang}

Luka merupakan suatu bentuk kerusakan jaringan pada kulit yang disebabkan kontak dengan sumber panas (seperti bahan kimia, air panas, api, radiasi, dan listrik), hasil tindakan medis, maupun perubahan kondisi fisiologis (Morris, P. J., Malt, R. A. 1990 dalam Purnama et al., 2017)

Masing-masing luka memiliki proses penyembuhan yang rumit karena adanya kegiatan bioseluler dan biokimia yang terjadi secara berkesinambungan. Dalam proses penyembuhan luka pascaoperasi akan memiliki risiko terkena infeksi pada luka, jika perawatan luka operasi yang diterapkan tidak sesuai dengan standar operasional prosedur (SOP). Risiko tersebut mengharuskan perawat untuk patuh dalam melakukan tindakan perawatan luka post operasi sesuai dengan SOP (Anggreani, 2016). Oleh kaena itu Djusmalinar \& Andriani, (2010 dalam Devi \& Wijayanti, 2013) menyebutkan penyebab infeksi diperkirakan masih banyaknya perawat yang mengabaikan standar operasional prosedur khususnya dalam perawatan luka.

Hasil penelitian sebelumnya yang dilakukan oleh (Anggreani, 2016), dengan judul "Gambaran Implementasi Prosedur Perawatan Luka Post Operasi Oleh Perawat Di RSU PKU Muhammadiyah Bantul” didapatkan hasil 56 perawat $(96,6 \%)$ dari 58 perawat sudah melakukan implementasi prosedur perawatan luka post operasi sesuai dengan SOP, sedangkan yang tidak sesuai dengan SOP 2 perawat $(3,4 \%)$ dan dari hasil persiapan alat dan bahan menunjukkan bahwa semua perawat $(100 \%)$ sudah menyiapkan alat dan bahan sesuai dengan SOP, tetapi ada 1 perawat yang menggunakan 1 alat untuk 2 pasien.

Hasil penelitian lainnya yang dilakukan oleh (Himatusujanah \& Rahayuningsih, 2008) "Hubungan Tingkat Kepatuhan Pelaksanaan Protap Perawatan Luka Dengan Kejadian Infeksi Luka Post Sectio Caesarea (SC) Di Ruang Mawar I RSUD dr. Moewardi Surakarta" didapatkan hasil sebagian besar perawat memiliki tingkat kepatuhan pelaksanaan protap baik, yakni sebanyak 26 $(60,5 \%)$ orang. Sedangkan perawat dan bidan yang memiliki tingkat kepatuhan pelaksanaan protap kurang, yakni sebesar 8 (18.6\%).

Dari hasil supervisi tingkat kepatuhan perawat dalam aplikasi SOP (Standar Operasional Prosedur) perawatan luka post operasi yang dilakukan oleh kepala ruang bedah RSUD dr. H. Andi Abdurrahman Noor pada tahun 2016 kepada 11 orang perawat. Dari hasil supervisi tersebut ada beberapa tindakan dalam SOP yang belum dilakukan seperti, tidak menanyakan nama pasien sebanyak 4 orang, tidak menjelaskan rasa ketidaknyamanan selam prosedur dilakukan sebanyak 4 orang, dan tidak melakukan pendokumentasian sebanyak 5 orang.

Berdasarkan studi pendahuluan yang dilakukan di Ruang Bedah RSUD dr. H. Andi Abdurrahman Noor Kabupaten Tanah Bumbu yang dilakukan kepada 8 orang perawat ruang 
bedah dan 2 orang perawat poli bedah, dengan menggunakan lembar observasi SOP perawatan luka yang didapatkan dari rumah sakit tersebut. Ada beberapa tindakan yang belum dilakukan sehingga dapat memepengaruhi proses penyembuhan luka seperti adanya 8 orang perawat yang tidak lagi menggunakan betadine karena merasa sudah tidak baik untuk digunakan dalam perawatan luka dan 2 diantaranya masih memakai betadine jika diminta oleh dokter, 2 orang tidak mengunakan pinset saat pembersihan luka, tidak menggunakan perlak atau pengalas sebanyak 2 orang, dan tidak menyiapkan gunting sebanyak 3 orang. Selain pada penggunaan alat, pada tahap tindakan juga ada sebagian perawat yang belum melakukan tindakan yang terdapat di SOP perawatan luka pascaoperasi, yaitu sebanyak 7 orang perawat tidak melakukan cuci tangan sebelum tindakan, 3 orang perawat membuka plester tanpa kapas alkohol, 4 orang perawat tidak membersihkan sisa plester, 1 orang perawat tidak menggunakan sarung tangan steril, 1 orang perawat dengan sengaja tidak menggunakan sufratul karena berdasarkan ilmu dan pengalaman yang didapatkan penggunaan sufratul atau sejenisnya akan membuat luka baru saat benda tersebut dilepas. Kemudian berdasarkan hasil observasi ada beberapa tindakan yang diduga dapat memengaruhi proses penyembuhan luka seperti pemakaian instrumen yang di gunakan secara bergantian dari satu pasien ke pasien lainnya, kemudian alat tersebut hanya direndam pada larutan alcohol untuk menyetrilkan alat tersebut. Beberapa perawat mengatakan terpaksa melakukan hal tersebut karena terbatasnya instrumen perawatan luka pada ruangan tersebut.

Dari pembahasan diatas peneliti tertarik untuk meneliti "Hubungan Tingkat Kepatuhan Perawat Terhadap SOP (Standar Operasional Prosedur) Perawatan Luka Dengan Proses Penyembuhan Luka Pasien Pascabedah di RSUD dr. H. Andi Abdurrahman Noor".

\section{Metode}

Jenis penelitian ini adalah penelitian korelasi dengan pendekatan cross sectional. Sampel dalam penelitian ini terdiri dari 2 kelompok, yang pertama seluruh perawat yang bertugas di ruang perawatan bedah dan poli bedah RSUD dr. H. Andi Abdurrahman Noor Kabupaten Tanah Bumbu berjumlah 20 orang dan pasien yang telah dilakukan perawatan luka pascabedah sebanyak 20 orang.

Kriteria inklusi sampel dalam penelitian ini, yaitu:

1. Pasien berusia 27 tahun sampai dengan usia 45 tahun.

2. Perawat yang bertugas pada ruang bedah, poli bedah dan pasien yang bersedia dijadikan responden.

3. Pasien yang telah menjalani proses pembedaahan dengan luka akut.

4. Pasien yang melakukan kontrol luka di ruang perawatan atau poli bedah. 
5. Laki-laki maupun perempuan.

Kriteria ekslusi sampel dalam penelitian ini yaitu:

1. Perawat yang bertugas pada ruang bedah, poli bedah dan pasien yang tidak bersedia dijadikan responden atau berhalangan untuk mengikuti penelitian, misalnya cuti, sakit kronis dan sebagainya.

2. Pasien yang tidak melakukan kontrol luka di ruang perawatan dan poli bedah.

3. Pasien yang mengikuti diet menyimpang, seperti tidak makan ikan atau daging selama proses penyembuhan.

Teknik sampling yang digunakan dalam penelitian ini adalah purposive sampling. Pengumpulan data dilakukan dengan lembar observasi tingkat kepatuhan perawat terhadap Standar Operasional Prosedur (SOP) perawatan luka pascabedah menggunakan SOP perawatan luka pascabedah yang didapatkan dari RSUD dr. H. Abdurrahman Noor Kabupaten Tanah Bumbu dan instrumen proses perkembangan luka didapatkan dari Suriadi tahun 2015.

\section{Hasil}

a. Karakteristik Responden

a. Responden Perawat

Dari hasil penelitian dapat dijelaskan tentang karakteristik respoden perawat menurut usia, jenis kelamin, Pendidikan, lama bekerja dan unit kerja seperti ditampilkan pada Tabel 1.
Tabel 1. Karakteristik pasien berdasarkan jenis kelamin, usia, jenjang pendidikan, status pekerjaan, agama, lama bekerja, dan unit kerja sebelumnya

\begin{tabular}{cccc}
\hline No & Karakteristik \\
Responden
\end{tabular} Parameter $\sum$ Persentase

\begin{tabular}{|c|c|c|c|}
\hline \multirow[t]{2}{*}{ 1. Jenis Kelamin } & Laki-Laki & 8 & $40 \%$ \\
\hline & Perempuan & 12 & $60 \%$ \\
\hline \multicolumn{2}{|l|}{ Total } & 20 & $100 \%$ \\
\hline \multirow[t]{2}{*}{ 2. Usia } & $\begin{array}{l}25 \text { s.d. } 30 \\
\text { Tahun }\end{array}$ & 16 & $80 \%$ \\
\hline & $\begin{array}{l}26 \text { s.d. } 35 \\
\text { Tahun }\end{array}$ & 4 & $20 \%$ \\
\hline \multicolumn{2}{|l|}{ Total } & 20 & $100 \%$ \\
\hline \multirow[t]{3}{*}{$\begin{array}{ll}\text { 3. } & \text { Jenjang } \\
& \text { Pendidikan }\end{array}$} & $\begin{array}{l}\text { DIII } \\
\text { Keperawatn }\end{array}$ & 7 & $35 \%$ \\
\hline & $\begin{array}{l}\text { SI } \\
\text { Keperawatan }\end{array}$ & 1 & $5 \%$ \\
\hline & $\begin{array}{l}\text { SI } \\
\text { Keperawatan } \\
+ \text { Ners }\end{array}$ & 12 & $60 \%$ \\
\hline \multicolumn{2}{|l|}{ Total } & 20 & $100 \%$ \\
\hline \multirow{3}{*}{$\begin{array}{ll}\text { 4. } & \text { Status } \\
& \text { Pekerjaan }\end{array}$} & Kontrak & 16 & $80 \%$ \\
\hline & Tetap & 0 & $0 \%$ \\
\hline & PNS & 4 & $20 \%$ \\
\hline \multicolumn{2}{|l|}{ Total } & 20 & $100 \%$ \\
\hline \multirow[t]{3}{*}{ 5. Agama } & Islam & 18 & $90 \%$ \\
\hline & $\begin{array}{l}\text { Kristen } \\
\text { Protestan }\end{array}$ & 1 & $5 \%$ \\
\hline & Kristen & 1 & $5 \%$ \\
\hline \multicolumn{2}{|l|}{ Total } & 20 & $100 \%$ \\
\hline \multirow[t]{3}{*}{ 6. Lama Bekerja } & $<5$ Tahun & 13 & $65 \%$ \\
\hline & $\begin{array}{l}6 \text { s.d. } 10 \\
\text { Tahun }\end{array}$ & 6 & $30 \%$ \\
\hline & $>11$ Tahun & 1 & $5 \%$ \\
\hline \multicolumn{2}{|l|}{ Total } & 20 & $100 \%$ \\
\hline \multirow{7}{*}{$\begin{array}{l}\text { 7. Unit Kerja } \\
\text { Sebelumnya }\end{array}$} & Ruang Bedah & 12 & $60 \%$ \\
\hline & $\begin{array}{l}\text { Ruang } \\
\text { Operasi }\end{array}$ & 3 & $15 \%$ \\
\hline & Ruang Anak & 1 & $5 \%$ \\
\hline & Ruang VIP & 1 & $5 \%$ \\
\hline & $\begin{array}{l}\text { Ruang } \\
\text { Rehabmedik }\end{array}$ & 1 & $5 \%$ \\
\hline & Laboratorium & 1 & $5 \%$ \\
\hline & IGD & 1 & $5 \%$ \\
\hline \multicolumn{2}{|l|}{ Total } & 20 & $100 \%$ \\
\hline
\end{tabular}

Sumber: Data Primer (2018).

Berdasarkan tabel 1 didapatkan hasil analisis karakteristik responden perawat di ruang bedah RSUD dr. H. Andi Abdurrahman Noor sebagian besar $(60 \%)$ berjenis kelamin perempuan sebanyak 12 orang. Sedangkan 
pada analisis usia hampir seluruhnya (80\%) berusia 25 s.d. 30 tahun sebanyak 16 orang.

Selanjutnya pada jenjang pendidikan sebagian besar $(60 \%)$ telah menyelesaikan pendidikan SI Kperawatan + Ners sebanyak 12 orang. Pada analisis status pekerjaan hampir seluruhnya $(80 \%)$ berstatus sebagai tenaga kontrak sebanyak 16 orang. Pada analisis agama hampir seluruhnya (90\%) sebanyak 18 orang beragama islam.

Kemudian pada analisis lama bekerja sebagian besar $(65 \%)$ bekerja kurang dari 5 tahun sebanyak 13 orang. Sedangkan pada analisis unit kerja sebelumnya sebagian besar (60\%) hanya bekerja di ruang bedah atau belum memiliki pengalaman kerja di unit kerja lain sebanyak 8 orang.

b. Responden Pasien

Dari hasil penelitian dapat dijelaskan tentang karakteristik respoden pasien menurut usia, jenis kelamin, pendidikan, pekerjaan dan agama seperti ditampilkan pada Tabel 2.

Tabel 2. Karakteristik responden pasien berdasakan jenis kelamin, usia, pendidikan terakhir, pekerjaan, agama

\section{No Karakteristik Parameter $\quad \sum$ Persentase Responden}

\begin{tabular}{|c|c|c|c|c|}
\hline \multirow{2}{*}{\multicolumn{2}{|c|}{$\begin{array}{ll}\text { 1. Jenis } \\
\text { Kelamin }\end{array}$}} & Laki-Laki & 17 & $85 \%$ \\
\hline & & Perempuan & 3 & $15 \%$ \\
\hline \multicolumn{2}{|c|}{ Total } & & 20 & $100 \%$ \\
\hline \multirow{2}{*}{\multicolumn{2}{|c|}{ 2. Usia }} & $\begin{array}{l}26 \quad \text { s.d. } \\
\text { Tahun }\end{array}$ & 12 & $60 \%$ \\
\hline & & 36 s.d. 45 Tahun & 8 & $40 \%$ \\
\hline \multicolumn{2}{|c|}{ Total } & & 20 & $100 \%$ \\
\hline \multirow{4}{*}{\multicolumn{2}{|c|}{$\begin{array}{l}\text { 3. Pendidikan } \\
\text { Terakhir }\end{array}$}} & $\begin{array}{l}\text { Tidak Tamat } \\
\text { SD }\end{array}$ & 2 & $10 \%$ \\
\hline & & SD & 4 & $20 \%$ \\
\hline & & SLTP & 6 & $30 \%$ \\
\hline & & SLTA & 8 & $40 \%$ \\
\hline \multicolumn{2}{|c|}{ Total } & & 20 & $100 \%$ \\
\hline & Pekerjaan & Tidak Bekerja & 2 & $10 \%$ \\
\hline
\end{tabular}

\begin{tabular}{llcc}
\hline No $\begin{array}{c}\text { Karakteristik } \\
\text { Responden }\end{array}$ & Parameter & $\sum$ & Persentase \\
\hline \multirow{2}{*}{} & Swasta & 15 & $75 \%$ \\
\cline { 2 - 4 } & PNS & 0 & $0 \%$ \\
\cline { 2 - 4 } & Petani & 1 & $5 \%$ \\
\cline { 2 - 4 } & $\begin{array}{l}\text { Ibu Rumah } \\
\text { Tangga }\end{array}$ & 2 & $10 \%$ \\
\hline Total & & $\mathbf{2 0}$ & $\mathbf{1 0 0 \%}$ \\
\hline 5. Agama & Islam & 20 & $100 \%$ \\
\hline Total & & $\mathbf{2 0}$ & $\mathbf{1 0 0 \%}$ \\
\hline Sumber
\end{tabular}

Sumber: Data Primer (2018).

Berdasarkan Tabel 2 responden pasien hampir seluruhnya (85\%) berjenis kelamin laki-laki sebanyak 17 orang. Sedangakan pada karakteristik usia sebagian besar (60\%) berusia sekitar 26 sampai dengan 35 tahun (dewasa awal) sebanyak 12 orang.

Selanjutnya pada karakteristik pendidikan hampir setengahnya (40\%) telah tamat SLTA (Sekolah Lanjutan Tingkat Atas). Kemudian pada karakteristik pekerjaan sebagian besar (75\%) berprofesi sebagai pekerja swasta sebanyak 15 orang. Sedangkan pada karakteristik agama seluruhnya (100\%) memeluk agama islam.

Pada analisis ini juga didapatkan karakteristik pembedahan dan diagnosa yang didapatkan dari pasien yang telah terpilih menjadi responden dan ditampilkan pada Tabel 3.

Tabel 3. Karakteristik pembedahan dan diagnosa

\begin{tabular}{|c|c|c|c|}
\hline $\begin{array}{c}\text { No Karakteristik } \\
\text { Pembedahan }\end{array}$ & Diagnosa & $\sum$ & Persentase \\
\hline \multirow{5}{*}{$\begin{array}{l}\text { Bedah } \\
\text { Ortopedi }\end{array}$} & Fraktur Tibia & 4 & $20 \%$ \\
\hline & Osteomyelitis & 1 & $5 \%$ \\
\hline & $\begin{array}{l}\text { Rupture Muscle } \\
\text { Deltoid }\end{array}$ & 1 & $5 \%$ \\
\hline & $\begin{array}{l}\text { Multiple Rupture } \\
\text { Tendon Digiti II, } \\
\text { III, IV }\end{array}$ & 1 & $5 \%$ \\
\hline & Fraktur Femur & 1 & $5 \%$ \\
\hline Total & & 8 & $40 \%$ \\
\hline 2. Bedah & Abses Gluteus & 2 & $10 \%$ \\
\hline Umum & Tumor Coli & 1 & $5 \%$ \\
\hline
\end{tabular}




\begin{tabular}{|c|c|c|c|}
\hline $\begin{array}{c}\text { No Karakteristik } \\
\text { Pembedahan }\end{array}$ & Diagnosa & $\sum$ & Persentase \\
\hline & Cervical & & \\
\hline & $\begin{array}{l}\text { Hernia Inguinalis } \\
\text { Lateralis (HIL) }\end{array}$ & 1 & $5 \%$ \\
\hline & Fistula Perianal & 1 & $5 \%$ \\
\hline & Abses Scrotum & 2 & $10 \%$ \\
\hline & Post Tracheostomy & 1 & $5 \%$ \\
\hline & $\begin{array}{l}\text { Abses } \\
\text { Submandibula }\end{array}$ & 1 & $5 \%$ \\
\hline & Selulitis & 2 & $10 \%$ \\
\hline & Vulnus Laceratum & 1 & $5 \%$ \\
\hline Total & & 12 & $60 \%$ \\
\hline
\end{tabular}

Sumber: Data Primer (2018).

Berdasarkan Tabel 3 didapatkan karakteristik pembedahan pasien sebagian besar $(60 \%)$ mendapatkan tindakan bedah umum.

c. Tingkat Kepatuhan Perawat Terhadap SOP Perawatan Luka

Dari hasil penelitian dapat dijelaskan tentang tingkat kepatuhan perawat terhadap SOP perawatan luka di Ruang Bedah RSUD dr. H. Andi Abdurrahman Noor seperti ditampilkan pada Tabel 4.

Tabel 4. Distribusi frekuensi tingkat kepatuhan perawat terhadap SOP (Standar Operasional Prosedur) perawatan luka pascabedah di RSUD dr. H. Andi Abdurraham Noor.

\begin{tabular}{llcc}
\hline No & \multicolumn{1}{c}{ Kelompok } & $\begin{array}{c}\text { Frekuensi } \\
\text { (orang) }\end{array}$ & $\begin{array}{c}\text { Persentase } \\
(\mathbf{\%})\end{array}$ \\
\hline 1. & Sangat Patuh & 8 & $40 \%$ \\
\hline 2. & Patuh & 8 & $40 \%$ \\
\hline 3. & Tidak Patuh & 2 & $10 \%$ \\
\hline 4. & Sangat Tidak Patuh & 2 & $10 \%$ \\
\hline Total & & $\mathbf{2 0}$ & $\mathbf{1 0 0 \%}$ \\
\hline
\end{tabular}

Sumber: Data Primer (2018).

Berdasarkan Tabel 4 dapat diketahui tingkat kepatuhan perawat terhadap SOP (Standar Operasional Prosedur) perawatan luka pascabedah hampir setengahnya (40\%) mempunyai tingkat kepatuhan yang sangat patuh sebanyak 8 orang. Hampir setengahnya lagi mempunyai tingkat kepatuhan dalam kategori patuh sebanyak 8 orang. Sebagian kecil (10\%) mempunyai tingkat kepatuhan dengan kategori tidak patuh sebanyak 2 orang. Sebagian kecilnya lagi (10\%) mempunyai tingkat kepatuhan dalam kategori sangat tidak patuh sebanyak 2 orang.

d. Tingkat Proses Penyembuhan Luka

Dari hasil penelitian dapat dijelaskan tentang tingkat proses penyembuhan luka di Ruang Bedah RSUD dr. H. Andi Abdurrahman Noor seperti ditampilkan pada Tabel 5.

Tabel 5. Distribusi frekuensi proses penyembuhan luka pasien pascabedah di RSUD dr. H. Andi Abdurraham Noor

\begin{tabular}{llcc}
\hline No & Kelompok & $\begin{array}{c}\text { Frekuens } \\
\text { i (orang) }\end{array}$ & $\begin{array}{c}\text { Persentase } \\
(\mathbf{\%})\end{array}$ \\
\hline 1. & Sangat Baik & 4 & $20 \%$ \\
\hline 2. & Baik & 3 & $15 \%$ \\
\hline 3. & Tidak Baik & 11 & $55 \%$ \\
\hline 4. & Sangat Tidak Baik & 2 & $10 \%$ \\
\hline Total & & $\mathbf{2 0}$ & $\mathbf{1 0 0 \%}$ \\
\hline
\end{tabular}

Sumber: Data Primer (2018).

Berdasarkan Tabel 5 dapat diketahui disrtibusi proses penyembuhan luka dengan kategori sangat baik sebagian kecil (20\%) sebanyak 4 orang. Sebagian kecil lainnya (3\%) berada dalam proses penyembuhan luka yang baik sebanyak 3 orang. Sebagian besar $(55 \%)$ berada pada tingkat penyembuhan dengan kategori tidak baik sebanyak 11 orang. Sebagian kecilnya lagi (10\%) dalam kategori penyembuhan luka yang sangat tidak baik sebanyak 2 orang.

e. Hubungan Tingkat Kepatuhan Perawat Terhadap SOP Perawatan Luka

Dari hasil penelitian dapat dijelaskan tentang hubungan Tingkat Kepatuhan 
Perawat Terhadap SOP Perawatan Luka dengan Proses Penyembuhan Luka Pascabedah di RSUD dr. H. Andi Abdurrahman Noor seperti ditampilkan pada Tabel 6.

Tabel 6. Hubungan antara tingkat kepatuhan perawat terhadap SOP (Standar Operasional Prosedur) perawatan luka dengan proses penyembuhan luka pascabedah di RSUD dr. H. Andi Abdurrahman Noor

\begin{tabular}{lccccc}
\hline \multirow{2}{*}{$\begin{array}{c}\text { Tingkat } \\
\text { Kepatuhan }\end{array}$} & \multicolumn{6}{l}{ Tingkat Penyembuhan Luka Total } & p-value \\
\cline { 2 - 6 } & $\begin{array}{c}\text { Sangat } \\
\text { Tidak } \\
\text { Baik }\end{array}$ & $\begin{array}{c}\text { Tidak } \\
\text { Baik }\end{array}$ & Baik & $\begin{array}{c}\text { Sangat } \\
\text { Baik }\end{array}$ & \\
\hline Sangat Tidak & 2 & 0 & 0 & 0 & 2 \\
Patuh & $100 \%$ & $0 \%$ & $0 \%$ & $0 \%$ & $100 \%$ \\
\hline Tidak Patuh & 0 & 2 & 0 & 0 & 2 \\
& $0 \%$ & $100 \%$ & $0 \%$ & $0 \%$ & $100 \%$ \\
\hline Patuh & 0 & 5 & 1 & 2 & 8 \\
& $0 \%$ & $62,5 \%$ & $12,5 \%$ & $25 \%$ & $100 \%$ \\
\hline Sangat Patuh & 0 & 4 & 2 & 2 & 8 \\
& $0 \%$ & $50 \%$ & $25 \%$ & $25 \%$ & $100 \%$ \\
\hline Total & 2 & 11 & 3 & 4 & 20 \\
& $10 \%$ & $55 \%$ & $15 \%$ & $20 \%$ & $100 \%$ \\
\hline
\end{tabular}

Sumber: Data Primer (2018).

Berdasarkan tabel 6 di atas dapat dilihat tingkat kepatuhan perawat dengan kategori sangat tidak patuh dengan kategori penyembuhan luka sangat tidak baik sebagian kecil (10\%) sebanyak 2 orang dan pada tingkat kepatuhan perawat dalam kategori yang tidak patuh dengan tingkat penyembuhan dengan katogori tidak baik memiliki nilai yang sama yaitu sebagian kecil (10\%) sebanyak 2 orang. Sedangkan pada tingkat kepatuhan perawat dengan kategori patuh dengan katogori penyembuhan luka yang baik sebagian kecil (10\%) sebanyak 2 orang. Selanjutnya pada tingkat kepatatuhan perawat dalam kategori patuh dengan proses penyembuhan luka dalam kategori tidak baik sebagian kecil (25\%) sebanyak 5 orang. Kemudian pada tingkat kepatuhan yang sangat patuh dengan proses penyembuhan luka yang tidak baik sebagian kecil (20\%) sebanyak 4 orang.

Berdasarkan hasil uji statistik menggunakan uji Spearmen Rank diperoleh nilai sig $(p=0,032)$ dengan tingkat kepercayaan $95 \%(\alpha=0,05)$ dengan kata lain $p 0,032<0,05$ maka H0 di tolak yang berarti terdapat hubungan antara tingkat kepatuhan perawat terhadap SOP perawatan luka dengan proses penyembuhan luka pasien pascabedah di RSUD dr. H. Andi Abdurrahman Noor.

\section{Pembahasan}

Berdasarkan hasil penelitian yang telah dilakukan di ruang Perawatan Bedah RSUD dr. H. Andi Abdurrahman Noor didapatkan bahwa tingkat kepatuhan perawat dengan kategori sangat tidak patuh dengan penyembuhan luka pasien dengan kategori yang sangat tidak baik sebagian kecil (10\%). Perawat dengan tingkat kepatuhan dalam kategori yang tidak patuh dengan penyembuhan luka dalam kategori tidak baik sebagian kecil (10\%). Kemudian perawat yang tingkat kepatuhannya dalam kategori patuh dengan penyembuhan luka dalam kategori tidak baik sebagian kecil (25\%). Sedangkan pada tingkat kepatuhan perawat dalam kategori sangat patuh dengan penyembuhan luka yang tidak baik sebagian kecil $(20 \%)$. 
Berdasarkan hasil uji statistik menggunakan uji Spearmen Rank diperoleh nilai sig $(p=0,032) \quad$ dengan tingkat kepercayaan $95 \%(\alpha=0,05)$ dengan kata lain $p$ $=0,032<0,05$ maka H0 di tolak yang berarti terdapat hubungan antara tingkat kepatuhan perawat terhadap SOP perawatan luka dengan proses penyembuhan luka pasien pascabedah di RSUD dr. H. Andi Abdurrahman Noor.

Dari data tersebut menunjukkan tingkat kepatuhan perawat dalam melakukan SOP perawatan luka pascabedah sebagian besar memiliki tingkat kepatuhan yang baik. Karena sudah sesuai dengan SOP yang ada dan selalu menggunakan teknik asepsis dalam setiap perawatan luka.

Hal ini sama dengan pendapat (Musta'an et al., 2011) dalam penelitiannya di RSUD dr. Moewardi Surakarta bahwa perawatan luka yang tidak menggunakan teknik septik dan aseptic akan menyebabkan terjadinya infeksi sehingga menghambat proses penyembuhan luka.

Pendapat (Safaruddin et al., 2020) dalam penelitiannya adalah menunjukkan bahwa dari 32 perawat yang menunjukkan kepatuhan dalam pelaksanaan SOP perawatan luka sebanyak 0 atau tidak ada yang menunjukkan kejadian infeksi, sedangkan dari 4 perawat yang menunjukkan ketidak patuhan dalam pelaksanaan SOP perawatan luka ada 3 perawat yang menunjukkan tidak adanya kejadian infeksi dan 1 perawat menunjukkan adanya kejadian infeksi.

\section{Pembahasan}

Hasil penelitian yang dilakukan oleh (Hastuti, 2010) juga mendapatkan hasil yang sama yaitu responden (perawat dan bidan) di ruang Mawar I RSUD DR. Moewardi Surakarta sebagian besar memiliki tingkat kepatuhan pelaksanaan protap baik, yakni sebesar 26 (60.5\%). Sedangkan perawat dan bidan yang memiliki tingkat kepatuhan pelaksanaan protap kurang, yakni sebesar 8 $(18.6 \%)$.

Pada penelitian ini menunjukkan bahwa sebagian besar (55\%) pasien memiliki tingkat penyembuhan luka yang kurang baik karena dipengaruhi oleh beberapa hal, seperti adanya tingkat kepatuhan perawat dalam menerapkan SOP perawatan luka pascabedah yang kurang baik dan adanya tahapan inflamasi luka saat dilakukan penilaian proses penyembuhan luka.

Hasil ini juga didukung dengan pendapat yang disampaikan oleh (Muhammad Suhada, 2021) bahwa penatalaksanaan luka yang tidak tepat akan menghambat proses penyembuhan luka hal yang perlu diperhatikan adalah keadaan sekitar luka seperti adanya kumpulan lemak dan kotoran disekitar luka harus dibersihkan.

Pendapat serupa juga disampaikan oleh (Ekaputra, 2013) bahwa produk perawatan dan pemberian pelayanan merupakan suatu hal yang sangat penting. Untuk itu kebersihan luka dan kebersihan lingkungan harus lebih di optimalkan agar terhindar dari resiko infeksi silang. 


\section{Kesimpulan}

Berdasarkan hasil penelitian yang dilakukan didapatkan kesimpulan sebagai berikut:

1. Hampir setengahnya (40\%) perawat di ruang perawatan bedah RSUD dr. H. Andi Abdurrahman Noor mempunyai tingkat kepatuhan terhadap SOP perawatan luka pascabedah dalam kategori yang sangat patuh dan hampir setengahnya (40\%) perawat dalam kategori patuh. Sedangkan sebagian kecil (10\%) perawat memiliki tingkat kepatuhan dengan kategori tidak patuh dan sebagian kecil (10\%) perawat dalam kategori sangat tidak patuh.

2. Sebagian besar (55\%) pasien di ruang perawatan bedah RSUD dr. H. Andi Abdurrahman Noor berada dalam kategori tingkat penyembuhan luka yang tidak baik dan sebagian kecil (20\%) pasien dalam kategori tingkat penyembuhan luka yang sangat baik. Sedangkan sebagian kecil $(15 \%)$ pasien memiliki tingkat penyembuhan luka dengan kategori yang baik dan sebagian kecil (10\%) pasien dalam kategori penyembuhan luka yang sangat tidak baik.

3. Terdapat hubungan antara tingkat kepatuhan perawat terhadap SOP perawatan luka dengan proses penyembuhan luka pasien pascabedah di RSUD dr. H. Andi Abdurrahman Noor.

\section{Ucapan Terimakasih}

Penulis mengucapkan terima kasih kepada Direktur Akper Pemkab Purworejo dan Ketua Lembaga Penelitian dan Pengabdian Masyarakat yang telah memberikan dukungan dalam penyelesaian publikasi ini.

\section{Daftar Pustaka}

Anggreani. (2016). Gambaran Implementasi Prosedur Perawatan Luka Post Operasi Oleh Perawat Di RSU PKU Muhammadiyah Bantul.

Devi, \& Wijayanti. (2013). Hubungan Motivasi Dengan Kepatuhan Perawat Pelaksana Dalam Melaksanakan Perawatan Lukapost Operasi Sesuaidengan SOP di RSUD Batang.

Ekaputra. (2013). Evolusi Manajemen Luka. TIM.

Hastuti, F. (2010). Gambaran Pelaksanaan Perawatan Luka Post Operasi Sectio Caesarea ( SC ) Dan Kejadian Infeksi Di Ruang Mawar I RSUD Dr. Moewardi. 6(1), 10.

Himatusujanah, \& Rahayuningsih, F. B. (2008). Perawatan Luka Dengan Kejadian Infeksi Luka Post Sectio Caesarea ( Sc ) Di Ruang Mawar I Rsud Dr . Moewardi Surakarta. Berita Ilmu Keperawatan, 1(4), 175-180.

Muhammad Suhada, F. P. (2021). Hubungan Antara Tingkat Kepatuhan Perawat Terhadap Sop (Standar Operasional Prosedur) Perawatan Luka Dengan Proses Penyembuhan Luka Pasien Pascabedah Di Rsud Dr. H. Andi Abdurrahman Noor. Nursing Science Journal (NSJ), 2(2), 55-64. https://doi.org/10.53510/nsj.v2i2.70

Musta'an, Supartono, \& Suwarni, A. (2011). Diffeerennce Effect Of Antibiotic Topical And Nacl 0,9\% Compress For Wounded 
Lead Process Post Operation In Anggrek Iii Room Rsud Dr. Moewardi Surakarta. http://download.portalgaruda.org.

Purnama, H., Sriwidodo, \& Ratnawulan, S. (2017). Review Sistematik: Proses Penyembuhan dan Perawatan Luka. Farmaka, 15(2), 255-256.

Safaruddin, H., Wardanengsih, E., \& Haerunnisa. (2020). Hubungan kepatuhan perawat dalam pelaksanaan sop perawatan luka dengan kejadian infeksi post op di rsud lamaddukkelleng sengkang kabupaten wajo. 2, 88-96. 